\title{
Paleoproterozoic $(\sim 1.88 G a)$ felsic volcanism of the Iricoumé Group in the Pitinga Mining District area, Amazonian Craton, Brazil: insights in ancient volcanic processes from field and petrologic data
}

\author{
RONALDO PIEROSAN ${ }^{1}$, EVANDRO F. LIMA ${ }^{2}$, LAURO V.S. NARDI ${ }^{2}$, CRISTINA P. DE CAMPOS $^{3}$, \\ ARTUR C. BASTOS NETO ${ }^{2}$, JOSÉ M.T.M. FERRON ${ }^{4}$ and MAURICIO PRADO ${ }^{4}$ \\ ${ }^{1}$ Programa de Pós-Graduação em Geociências (PPGGeo), Instituto de Geociências, \\ Universidade Federal do Rio Grande do Sul (UFRGS), Av. Bento Gonçalves, 9500, 91501-970 Porto Alegre, RS, Brasil \\ ${ }^{2}$ Centro de Pesquisas em Geoquímica (CPGq), Instituto de Geociências, Universidade Federal do Rio Grande do Sul (UFRGS), \\ Av. Bento Gonçalves, 9500, Caixa Postal 15001, 91501-970 Porto Alegre, RS, Brasil \\ ${ }^{3}$ Department für Geo- und Umweltwissenschaften, Ludwig-Maximilians-Universität München (LMU), \\ 1 Theresienstrasse, 41.80333, München, Deutschland, Germany \\ ${ }^{4}$ Mineração Taboca S.A. - Grupo Paranapanema, Presidente Figueiredo, 69735-000 Vila Pitinga, AM, Brasil
}

Manuscript received on August 31, 2009; accepted for publication on January 1, 2011

\begin{abstract}
The Iricoumé Group correspond to the most expressive Paleoproterozoic volcanism in the Guyana Shield, Amazonian craton. The volcanics are coeval with Mapuera granitoids, and belong to the Uatumã magmatism. They have $\mathrm{U}-\mathrm{Pb}$ ages around $1880 \mathrm{Ma}$, and geochemical signatures of A-type magmas. Iricoumé volcanics consist of porphyritic trachyte to rhyolite, associated to crystal-rich ignimbrites and co-ignimbritic fall tuffs and surges. The amount and morphology of phenocrysts can be useful to distinguish lava (flow and dome) from hypabyssal units. The morphology of ignimbrite crystals allows the distinction between effusive units and ignimbrite, when pyroclasts are obliterated. Co-ignimbritic tuffs are massive, and some show stratifications that suggest deposition by current traction flow. Zircon and apatite saturation temperatures vary from $799^{\circ} \mathrm{C}$ to $980^{\circ} \mathrm{C}$, are in agreement with most temperatures of A-type melts and can be interpreted as minimum liquidus temperature. The viscosities estimation for rhyolitic and trachytic compositions yield values close to experimentally determined melts, and show a typical exponential decay with water addition. The emplacement of Iricoumé volcanics and part of Mapuera granitoids was controlled by ring-faults in an intracratonic environment. A genesis related to the caldera complex setting can be assumed for the Iricoumé-Mapuera volcano-plutonic association in the Pitinga Mining District.
\end{abstract}

Key words: Amazonian Craton, caldera complex, ignimbrite, Iricoumé volcanism, surge deposits, Uatumã magmatism.

\section{INTRODUCTION}

About 1.1 million $\mathrm{km}^{2}$ of the Amazonian Craton (Guyana and Guaporé Shields) is covered by the Uatumã Supergroup. This magmatic province consists of a predominantly felsic volcano-plutonic association, with ages around $1.88 \mathrm{Ga}$ and geochemical signatures of Atype magmas (Dall'Agnol et al. 1987, 1994, 1999a, Tassinari and Macambira 1999, Tassinari et al. 2000, Santos et al. 2000, 2004).

Correspondence to: Ronaldo Pierosan

E-mail: ronaldo.pierosan@ufrgs.br
Volcanic rocks of the Iricoumé Group are widespread over the Guyana Shield. They were firstly identified in the XIX century when Derby (1877) described along the Uatumã River an amorphous feldspathic rock with quartz grains, which the author classified as felsite or eurite (Araujo et al. 1976). Since then, several authors (Albuquerque 1922, Oliveira and Leonardos 1940, Oliveira et al. 1975, Basei 1977, Melo et al. 1978, Veiga Jr. et al. 1979, Costi et al. 1984, Schobbenhaus et al. 1994, Faria et al. 2000, Tassinari and Macambira 1999, Santos et al. 2000, Costi et al. 2000, Valerio et al. 2009, 
Ferron et al. 2010) mapped and studied the geochemical and geochronological aspects of these volcanic sequences, and pointed out to their relation with granitic bodies of similar characteristics and to the Uatumã Magmatism.

In the Pitinga Mining District, Iricoumé volcanics outcrop dominantly as felsic rocks that were intruded by the mineralized ( $\mathrm{Sn}-\mathrm{Nb}-\mathrm{Ta}-\mathrm{F}$ ores) granitic bodies of the Madeira Suite $(\sim 1.83 \mathrm{Ga})$. Since the primary cassiterite mineralization was discovered in the beginning of the $80 \mathrm{~s}$, the geologist concern has been concentrated mainly on the mineralized bodies. The regional geological mapping published by Veiga Jr. et al. (1979) defined most of the geological units in the Pitinga Mining District and vicinities. First $\mathrm{U}-\mathrm{Pb}$ and $\mathrm{Pb}-\mathrm{Pb}$ geochronology of Iricoumé Group in the area was presented by Schobbenhaus et al. (1994) and Costi et al. (2000), yielding ages of $1.96 \mathrm{Ga}$ and $1.88 \mathrm{Ga}$, respectively. Costi et al. (2000) suggested that the relation of Iricoumé volcanics with the mineralized granites (Madeira Suite) should be abandoned. Ferron et al. (2007, 2010) have presented detailed geochemical and geochronological studies concerning the Iricoumé Group genesis and its relation with the coeval subvolcanic bodies of the Mapuera Suite. They concluded that the Iricoumé Group has A-type magma signatures and ages varying from $1.88 \mathrm{Ga}$ to $1.90 \mathrm{Ga}$. A genetic relation of Iricoumé volcanics with Mapuera granitoids was established. Detailed studies concerning the genesis of the Iricoumé lithofacies and its volcanic processes, have not been fully explored.

In this manuscript we provide detailed information on lithofacies and stratigraphy of the Iricoumé volcanics in Pitinga area. By using the whole rock geochemical data, we also calculated physical parameters, such as zircon and apatite saturation temperatures and viscosities. Although the results are rather qualitative, some important conclusions on ancient volcanic processes and environment and their relation to the Pitinga Mining District geology, will be discussed.

\section{LOCAL GEOLOGY}

The geology of Pitinga Mining District is composed dominantly by unmetamorphosed magmatic and sedimentary assemblages emplaced and deposited on a granitic-metamorphic basement (Fig. 1). This basement consists of gneisses of amphibolite to granulite facies, associated with migmatites and granitoids, which are grouped in the Guianense Complex $(\sim 2.10 \mathrm{Ga})$, and calc-alkaline granitoids of Água Branca Suite (1.96$1.89 \mathrm{Ga})$.

Volcanics of the Iricoumé Group are expressive in the area and consist dominantly of porphyritic andesite to rhyolite, associated to ignimbrite and acid tuffs (Ferron et al. 2007). Quartz syenites to alkali-feldspar granites of the Mapuera Suite have been interpreted as comagmatic with Iricoumé volcanics (Veiga Jr. et al. 1979, Ferron et al. 2007, 2010). Both units have similar ages $(1.90$ to $1.88 \mathrm{Ga})$ and a geochemical affinity compatible with A-type magma (Costi et al. 2000, Ferron et al. 2010). Therefore, they have been included in the Uatumã Magmatism (Melo et al. 1978, Veiga Jr. et al. 1979, Costi et al. 2000, Ferron et al. 2007, 2010). The Iricoumé-Mapuera volcano-plutonic activity is followed by the intracratonic deposition of quartz sandstones, arkoses, conglomerates and pyroclastic rocks of the Urupi Formation (Veiga Jr. et al. 1979). Ignimbrites and acid tuffs that occur interbedded with the Urupi sediments have been recognized as the final stages of the Iricoumé volcanic activity (Ferron et al. 2007).

The mineralized granitoids of Madeira Suite were emplaced at around $1.83 \mathrm{Ga}$ ago in an entirely anorogenic setting, and represent an outstanding Sn and $\mathrm{Nb}$-Ta ore producers (Horbe et al. 1991, Lenharo 1998, Costi et al. 2000, Lenharo et al. 2003). Mafic to intermediate tholeiitic rocks of the Quarenta Ilhas Formation have $\sim 1.78 \mathrm{Ga}$ and consist of subvolcanic bodies emplaced throughout pre-existing ring structures (Veiga Jr. et al. 1979, Santos et al. 2002).

\section{MATERIALS AND METHODS}

Field work was based on previous geological and exploration mapping and point maps available from Mineração Taboca S.A. - Paranapanema Group. The areas containing the main volcanic structures and key outcrops were selected for this study. More than 150 samples were collected of which 47 were selected for petrography and geochemical studies. Three thin sections of the typical volcanic lithotypes (1 rhyolitic lava, 1 hypabyssal rhyolite and 1 rhyolitic ignimbrite) were selected for phenocrysts characterization and quantification. Petrographic features as rock fragments 


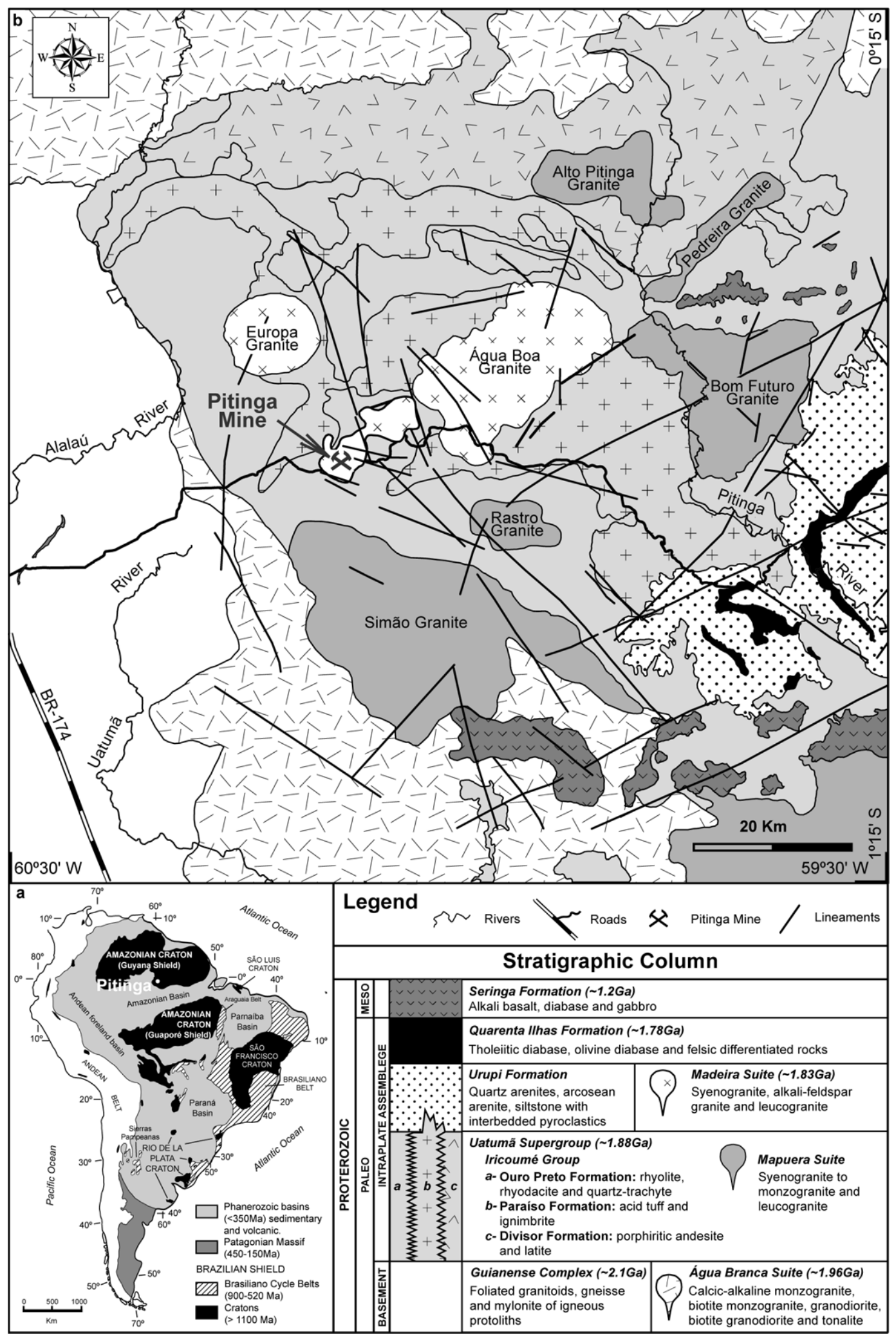

Fig. 1 - Location (a) and geological map (b) of Pitinga Mining District. (modified from (a) Hartmann and Delgado 2001 and (b) Ferron et al. 2007). 
absence and few secondary minerals were the main criteria for rhyolite samples selection. The ignimbrite sample was chosen from a key outcrop in the area, with a good exposure of a crystal-rich ignimbrite, avoiding rock fragments.

The whole rock chemical analyses were carried out by Activation Laboratories Ltd (Actlabs). The major elements were analyzed through the ICP-OES procedure, and $\mathrm{Zr}$ through ICP-MS. Fluorine was analyzed by ISE. The major elements and fluorine are expressed as wt.\% and $\mathrm{Zr}$ as ppm. Zircon and apatite saturation temperatures were calculated in a dataset of twentytwo samples (eight trachytes and fourteen rhyolites). For these calculations, was used the zircon and apatite saturation methods (Watson 1979, Watson and Harrison 1983, Hanchar and Watson 2003) was run through GCDkit software (Janousek et al. 2006). Four samples of effusive rocks (two trachytes and two rhyolites) with low secondary minerals content and low loss of mobile elements were selected for the estimation of melt viscosity.

Viscosity data were calculated using the whole rock analysis through the empirical non-Arrhenian Newtonian model for multicomponent silicate melts of Giordano et al. (2008). The calculation is based on major elements, fluorine and $\mathrm{H}_{2} \mathrm{O}$ contents, and was run through an Excell ${ }^{\circledR}$ spreadsheet available on:

http://www.eos.ubc.ca/ krussell/VISCOSITY/grdViscosity.html. For this calculation, we assume that the bulk rock composition approximates to the original melt composition. The purpose of this calculation is to achieve approximated viscosity using estimated liquidus temperature, and compare with those measured from melt compositions (Goto et al. 2005, Giordano et al. 2006, 2008).

\section{FIELD AND PETROGRAPHIC CHARACTERISTICS OF THE IRICOUMÉ GROUP}

The volcanic rocks of the Iricoumé Group cover an area of around $4,500 \mathrm{~km}^{2}$ in the Pitinga Mining District. They outcrop mainly as metric to decametric boulders and bedrocks along creeks and rivers margins, both without significant lateral continuity. Therefore, petrographic features as phenocryst content, shape and orientation and groundmass characteristics, become important parameters for distinguishing the volcanic lithofacies in the area.
Lava (flow and dome) and hypabyssal rocks are dominant among all volcanic units, while ignimbrites are dominant over the other pyroclastic rocks. The amount, shape and size of phenocrysts become the main feature for distinguishing between lava and hypabyssal units. Most of the ignimbrite occurrences do not show typical characteristics of volcanic rocks originated by hot pyroclastic flows, as lithic and/or vitric fragments, and of those originated by welding processes. Thus, low contents of fragmented phenocrysts consist the main feature for distinguishing lava and hypabyssal units from ignimbrites lacking diagnostic welding features.

\section{Phenocryst CONTENTS AND CHARACTERISTICS}

From a study focusing the phenocryst fragments features of rhyolitic lava and ignimbrites from Taupo Volcanic Zone (New Zealand) and Yali, Nisyros and Milos volcanism (Greece), Allen and McPhie (2003) pointed out to the importance of criteria to discriminate lava from pyroclastic facies, especially in ancient, deformed, altered and/or poorly exposed volcanic successions. The authors defined that the abundance and shape of phenocrysts, as well as the amount of fragmented phenocrysts among the total content of crystals, are important parameters to discriminate lava from pyroclastic facies. Based on these principles, three representative thin sections of Iricoumé volcanics were photographed and digitalized: one sample of rhyolite from a lava dome, one hypabyssal rhyolite and one rhyolitic crystal-rich ignimbrite from the middle portion of a pyroclastic flow unit. Phenocrysts and crystal abundances were calculated based on the area occupied by grains and groundmass.

Phenocrysts in rhyolitic lava are medium (1-5 mm) to fine $(<1 \mathrm{~mm})$ grained, and comprise $\sim 10$ modal $\%$ of the rock. Feldspar phenocrysts are originally euhedral to subhedral. Alkali feldspar is characterized as nearly equant prismatic crystals, while plagioclase is dominantly tabular of prismatic shape. Mesoperthite lamellae with almost equal proportions between orthoclase and albite components occur frequently within alkali feldspar, whereas the plagioclase has polysynthetic twinning and weak compositional zoning. Glomeroporphyritic aggregates consisting of fine to medium grained feldspar phenocrysts of subhedral to euhedral form can 
be observed locally and may represent rock fragments. Feldspar fragments are common and consist mainly of broken euhedral phenocrysts of medium size, with straight to irregular margins. Triangular and smaller fragments from strongly fractured phenocrysts can be found scattered throughout the thin section. Quartz phenocrysts are usually euhedral, medium grained, with reabsorption features. When fragmented, they show small splinter forms with sharp and curved margins.

Crystal abundances in rhyolitic ignimbrite stand at around 30 modal\% and are medium to fine grained. Feldspars are similar to those described for the rhyolitic lava. However, fragments predominate over euhedral or subhedral shapes. Small anhedral fragments, frequently detached from strongly fractured phenocrysts, are more abundant than slightly broken subhedral phenocrysts. Similarly, conjugate fragments dislocated and separated only by a thin portion of groundmass, forming a jigsawfit arrangement, are very common in Iricoumé rhyolitic ignimbrites. Quartz crystals are medium to fine grained and show intense reabsorption features.

Phenocrysts in the hypabyssal rhyolite reach up to 40 modal $\%$ and consist of medium to coarse $(>5.0 \mathrm{~mm})$ grains with less fine grains. Phenocrysts are anhedral to subhedral feldspars and quartz grains, usually with intense reabsorption features. Glomeroporphyritic aggregates of subhedral and medium size grains are commonly observed and can be interpreted as rock fragments. Subhedral phenocryst fragments with few straight and broken margins are common. Smaller grains tend to be subhedral with rounded shapes.

The investigation of phenocrysts abundances and characteristics, in samples of the Iricoumé volcanism in the Pitinga Mining District area supports the recognition of distinct features among rhyolitic lava, hypabyssal rhyolite and rhyolitic ignimbrite. Rhyolitic ignimbrite and rhyolitic lava contain originally medium phenocrysts, which are predominantly euhedral to subhedral. While common broken margins are dominant in rhyolitic lava, strongly fragmented and euhedral edges prevail in rhyolitic ignimbrite. The amount of crystals in the ignimbrite is three-fold higher than in the rhyolitic lava. This feature is indicative of physical fractionation from a probable elutriation process. This enrichment is considerably higher in ignimbrites with coarse lithic fragments observed in the base of a pyroclastic flow unit. Reabsorption features in quartz grains are observed with similar intensity and frequency in rhyolitic lava and ignimbrite. Quartz phenocrysts in hypabyssal rhyolite, on the other hand, tend to be anhedral to subhedral, medium- to coarse-grained, with abundant and intense reabsorption features. Fragments, however, are less frequent than in rhyolitic lava and show straight broken margins.

\section{EFFusive UNits (LAVA FLOW AND DOME, AND \\ HYPABYSSAL ROCKS)}

Porphyritic rhyolite and trachyte have phenocrysts modal contents varying from $8 \%$ to $40 \%$. Lava flow and dome usually host a low content of phenocrysts (around 10\%), mostly euhedral with common reabsorption features and few fragmented terminations. Hypabyssal rocks host higher phenocryst contents ( $>10 \%$ to $40 \%$ ) of which showing subhedral to euhedral shapes, frequent and intense reabsorption features, and common fragmented terminations.

The phenocrysts in effusive rhyolites (lava and hypabyssal) consist mainly of alkali-feldspar and quartz with less frequent plagioclase. Trachytes differ petrographically from rhyolites by the lack of quartz phenocrysts, consisting of rare and small quartz phenocrysts. Hornblende occurs rarely in a few trachyte and rhyolite samples, and show pale-brown to bluish-green pleochroism with subhedral to euhedral shape (Fig. 2a). Green biotite and Fe-Ti oxides are common as subhedral grains within the groundmass. Apatite is the main accessory mineral in trachyte, and show euhedral to subhedral shapes and dimensions from 0.15 to $0.6 \mathrm{~mm}$. Zircon is frequent in rhyolite, showing a compositional zoning usually observed in magmatic crystals, euhedral to subhedral forms and 0.1 to $0.5 \mathrm{~mm}$. Titanite and some allanite are present subordinately in the whole compositional trend.

The groundmass is mostly quartz-feldspathic in composition, and in rhyolitic lava is fine phaneritic to aphanitic and originally vitric as well. The fine phaneritic matrix from lava flow and dome shows locally a micropoikilitic texture that, allied to spherulitic intergrowing within the aphanitic groundmass, suggests devitrification processes. In the hypabyssal rhyolite, the 
fine phaneritic groundmass shows a common anhedral intergranular quartz (Fig. 2b) and locally granophyric intergrowing, which may indicate the crystallization of a quartz-feldspathic residual melt under relatively lower cooling rates. Vertical orientation of phenocrysts is observed locally in hypabyssal rhyolites and suggests vertical magmatic flow in feeder dike.

Flow foliation is frequently observed in rhyolitic and trachytic lava flow and dome. It varies from moderate, with microlites orientation mainly around the phenocrysts corners, to well-developed, forming flow layering. Flow layering (Dadd 1992) occurs locally in a rhyolite dome in the northern portion of the area (see Fig. 5), and consists of a structure with planar to stretched and folded layers (Fig. 2c) and predominantly subvertical orientation. This fabric is characterized by the interbedding of thin layers with different crystallization degrees, since primary vitric to fine phaneritic (Fig. 2d). The rotation of unbroken phenocrysts could have been promoted by shear stress as the laminar viscous flow evolved (Fig. 2e). Elongated vesicles along the layering were only seldom observed (Fig. 2f), suggesting at least local volatile oversaturation. Chlorite, epidote and part of opaque minerals are possibly related to latemagmatic fluids and metassomatism. These fluids concentrate mainly in the midst of fine phaneritic layers and vesicles. In the flow-layered rhyolite, despite the lack of micropoikilitic texture and spherulite, the layering structure may have been enhanced by devitrification. Flow bands, folds and elongated vesicles can be a diagnostic feature of silicic lava flows (Henry et al. 1990). The restrict clast size variation, low content of fragmented phenocrysts and lithic, that are common features of ignimbrites, are also suggestive of an effusive origin.

\section{PYROCLASTIC ROCKS}

\section{Ignimbrites}

Ignimbrites have trachytic to rhyolitic compositions. Based on the clast size classification (Le Maitre 2002), the ignimbrites can be named as lapilli tuff. Lapilli size components are dominantly composed of crystals and subordinate lithic fragments, which rarely reach block size. The matrix consists of fine ash to dust size crystal and vitric fragments.
The main lithofacies is characterized by a high amount of juvenile crystal fragment with less vitric fragments. The matrix is fine ash grained. Lithic cognate and accidental fragments occur only locally. Lapilli grained crystals (phenoclasts) are dominantly alkalifeldspars and subordinate quartz and plagioclase. They show abundant fragmented shapes and less euhedral terminations, possibly as a result of explosive eruption and turbulent flow. Intense reabsorption features suggest deposition under still high temperature. Phenoclasts content reach 35 modal\%, which is considerably higher than the amount of phenocrysts content in the lava flow and dome $(\sim 10 \%)$. Denser fragments enrichment points towards physical fractionation and sorting processes associated with the eruption and transportation (elutriation processes), as suggested by Cas and Wright (1987). Such features are suggestive of the deposition of a pyroclastic flow with high particle concentrations, and the ignimbrites would represent a portion of the internal layer of a pyroclastic flow unit (Sparks and Walker 1973, Cas and Wright 1987).

The outcrop shown in Figure 2g-n could be interpreted as an intermediate layer of an idealized pyroclastic flow unit, which consists of ignimbrites with reverse grading of low density vitric fragments and normal grading of denser lithic fragments. Crystal fragments tend to concentrate slightly more in the lower part than in the upper part. The lowest and upper layers of an idealized pyroclastic flow unit, base surge and ash cloud surge, were not observed in this outcrop.

The originally vitric fragments consist mainly of lens-shaped massive fiamme to thin and stretched fiamme that, in higher amounts, form an eutaxitic texture. In an outcrop scale, the welding feature is recognized as horizontal to subhorizontal bedding structure (Fig. 2h). Stretched fiamme are usually found moulded against the sharp corners of crystals (Fig. 2i). This is indicative of welding compactation processes, especially when allied to perlitic cracks and spherulitic intergrowing in glassy matrix and/or vitric fragments (Gifkins et al. 2005). Deformed vesicles (Fig. 2j) can also indicate compactation processes.

Different intensities of devitrification processes are characterized by perlitic cracks (Fig. 2k), spherulitic to axiolitic intergrowing in fiamme (Fig. 21), and 

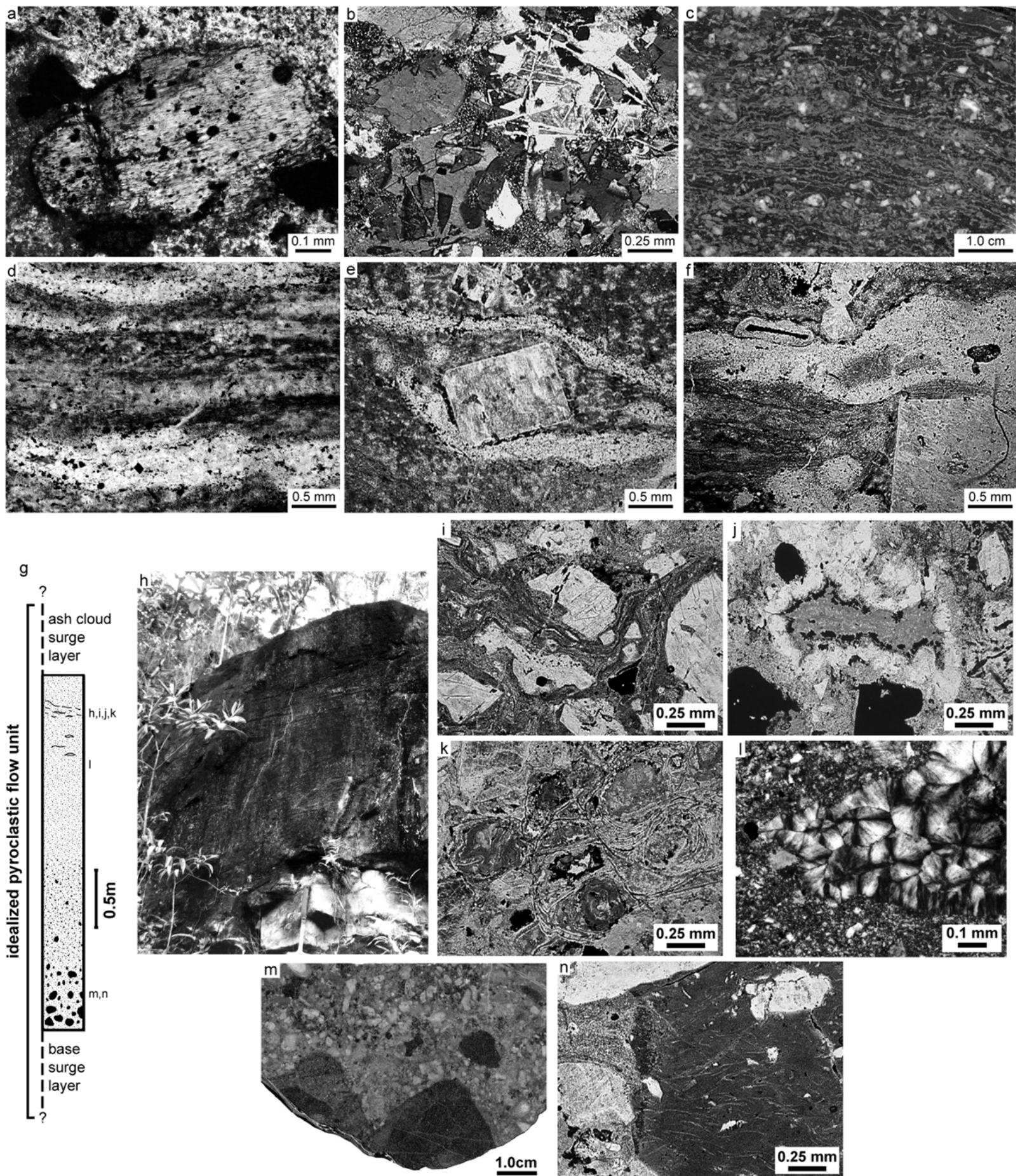

Fig. 2 - Petrographic features of coherent units and ignimbrites. a) subhedral hornblende rounded by thin layer of leucoxene in effusive trachyte; b) micropoikilitic texture and acicular quartz in hypabyssal rhyolite; c) flow foliation in hand-specimen of effusive rhyolite; d) interbedding of fine phaneritic to vitric layers of the foliated rhyolite; e) euhedral phenocryst rotated by flow; f) elongated vesicle along the flow foliation; g) idealized section of a pyroclastic flow unit; h) top of intermediate showing subhorizontal eutaxitic structure; i) eutaxitic texture in thin section of an ignimbrite; j) compacted vesicle filled with quartz, opaque minerals and chlorite; k) perlitic cracks in an originally glassy matrix; 1) devitrification features: spherulitic intergrowing at the centre of the fiamme and axiolitic intergrowing at the edge; $\mathrm{m}$ ) hand specimen of a ignimbrite with cognate lithic clasts; n) Y- U-shaped and bubble-wall shards within a cognate lithic clast (center-left portion). 
micropoikilitic textures in a glassy matrix. Lithic fragments consist mainly of cognate rocks such as fine tuffs, which are composed by crystals and Y- and U-shaped shards fragments (Fig. 2m, n).

\section{Co-ignimbritic tuffs}

Massive and stratified tuffs are well sorted, and finegrained deposits occur associated to ignimbrites. Tuffs are composed by crystal and lithic fragments, in which crystals widely predominate over lithic fragments. Vitric fragments are not observed. However, they can have been obliterated by weathering. Massive tuffs consist of thick and homogeneous beds, lacking grain size gradation. They mainly consist of angular quartz and feldspar fragments, with irregular borders that could indicate a juvenile origin. Lithic components consist of angular fragments of tuffaceous cognate rocks. An origin related to fallout tuff deposit could be suggested for the massive tuffs.

The components of stratified deposits are the same as those from massive tuffs. In turn, the bedsets vary from 20 to $50 \mathrm{~cm}$ thick, with planar, wavy and crossbedded stratifications. Bedforms are internally well sorted and predominantly massive, without vertical grading. Figure 3 shows a representative outcrop of at least six successive well-stratified deposits (Fig. 3a, b). All bedsets have massive internal layers showing only local organization (Fig. 3c, d). Bedset 1 consists of a $\sim 50 \mathrm{~cm}$ thick layer with very regular planar stratification, with thicknesses of around $3.0 \mathrm{~cm}$. Bedset 2 lies conformably on bedset 1 (Fig. 3e), and its planar stratification is characterized by a thickness increase toward the inner portion of the layer. Bedset 3 depicts long wavelength cross stratification, consisting of a low angle stratification at the base and grading up to $\sim 30^{\circ} \mathrm{dip}$ at the top. There, it makes an erosional boundary with the upper bedset (Fig. 3f). The fourth bedset consists of a $\sim 25 \mathrm{~cm}$ thick layer with wavy-planar stratification. Cognate lithic fragments are sparsely disposed along a well-defined level close to the top of the bedset 4, with size varying from $<1$ to $4 \mathrm{~cm}$ (Fig. $3 \mathrm{~g}$ ). Soft deformation and layering rupture, just below the lithics (Fig. 3h) suggest that lithics fragments were ejected as ballistic fragments. Bedsets 5 and 6 are characterized by wavy- planar stratification varying laterally to short wavelength cross stratification (Fig. 3i).

Most features described in the stratified deposits of the Iricoumé Group in the Pitinga Mining District, such as grain size, sorting and bedforms, are usually observed in modern pyroclastic surge deposits (Sparks and Walker 1973, Fisher 1979, Allen 1982, Cas and Wright 1987). The increased thickness of planar lamination, as observed in bedset 2 , can be related to higher particle concentrations and faster deposition rates. Thinner planar lamination, as well as cross-stratification, would reflect lower particle concentrations (Cas and Wright 1987). Other variations, such as wavy-planar lamination grading to cross-stratification (bedsets 5 and 6) and changes of repose angle of cross-stratification (bedset 3 ), could be related to a more complex flow regime, involving different deposition rates, temperature and moisture contents (Allen 1982, Cas and Wright 1987, Allen and Cas 1998).

Genetic relations between stratified deposits with their supposed source vents or parental pyroclastic flow units could not be established in the Pitinga region. Some characteristics of the stratified deposits in this area, such as the change in the layer thickness and the deposition of successive surge layers, are usually observed in other base surge deposits. On the other hand, well-sorted ash grained deposits are typical features of ash-cloud surge. Therefore, based on the spatial relation between stratified deposits and ignimbrites that underwent physical fractionation in the studied area, one could suggest an origin related to elutriation processes.

\section{PHYSICAL PARAMETERS}

The use of physical parameters based on chemical composition, such as liquidus temperatures and viscosity, is herein applied with the purpose of testing how the current composition of Iricoumé volcanics approximate to an original melt. Geochemical data of the Iricoumé volcanics in the Pitinga Mining District (Ferron et al. 2010) have indicated little chemical changes due to metassomatism, weathering and recrystallization processes. In this study, major elements, $\mathrm{Zr}$ and $\mathrm{F}$ of representative samples were used for liquidus temperature and viscosity estimation. 

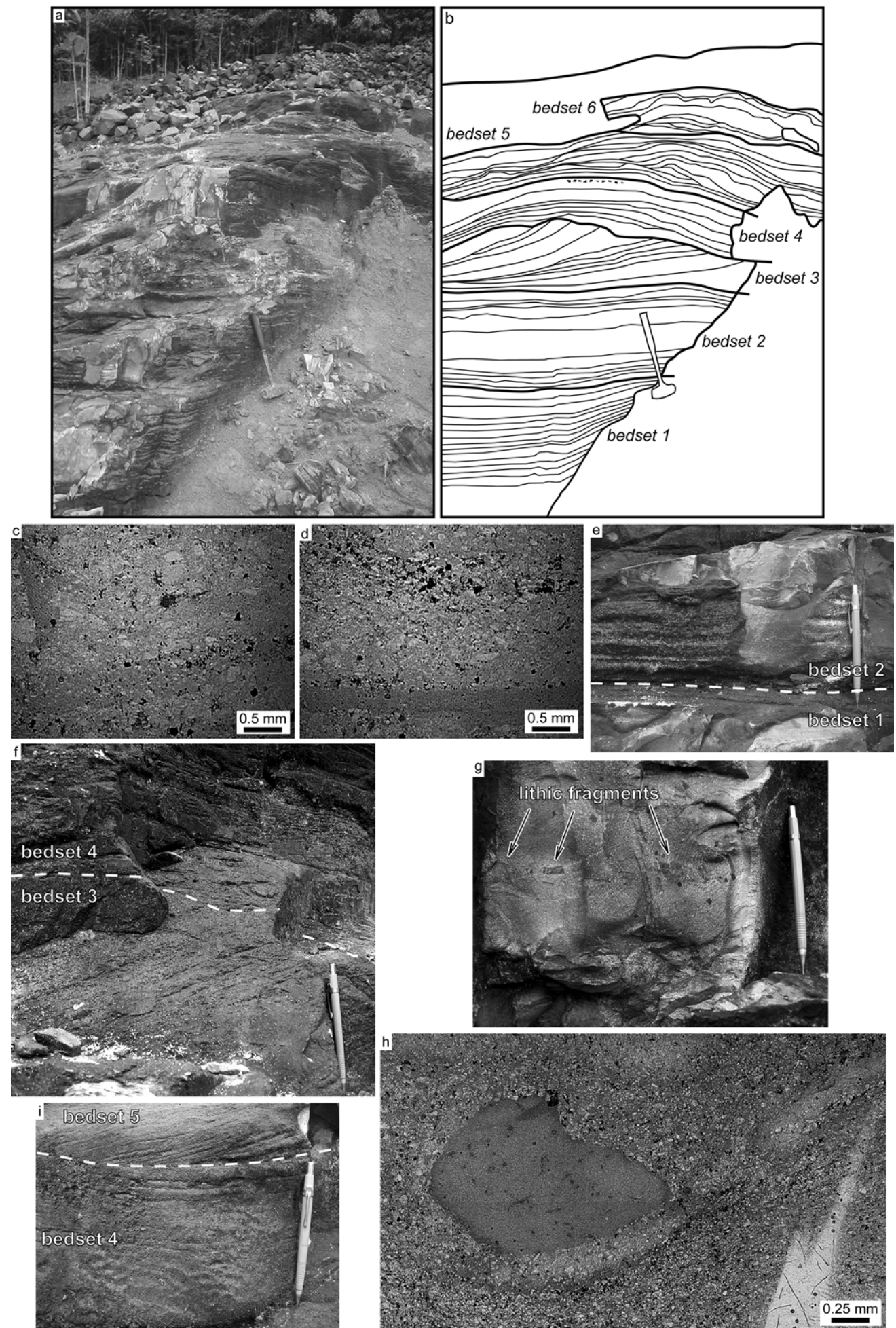

Fig. 3 - Field and petrographic characteristics of the surge deposits of the Iricoumé Group: a) outcrop A13 - see Figure 5 for location; b) Sketch of outcrop A13 showing the six bedsets; c) microscopic feature showing the dominant massiveness of co-ignimbritic deposits; d) internal organization of the surge deposits; e) plane parallel stratification in weathered and fresh surface close to the boundary between sets 1 and 2; f) erosional boundary between bedsets 3 and $4 ; \mathrm{g}$ ) level of lithic fragment close to the top of the bedset 4 ; h) tuffaceous cognate lithic fragment with dropping feature in thin section; i) low-angle truncation between bedsets 4 and 5 . 


\section{ZIRCON AND APATITE SATURATION TEMPERATURES}

Zircon and apatite saturation method (Watson 1979, Watson and Harrison 1983, Hanchar and Watson 2003) can be applied as a geotermometer for metaluminous acid melts, with $\mathrm{H}_{2} \mathrm{O}>2 \%$ and $\mathrm{M}$ parameter values $[\mathrm{M}=(\mathrm{Na}+\mathrm{K}+2 \times \mathrm{Ca}) /(\mathrm{Al} \times \mathrm{Si})]$ between 0.9 and 1.7 (Hanchar and Watson 2003). The estimated saturation temperatures of zircon $\left(\mathrm{T}_{\mathrm{zr}}\right)$ and apatite $\left(\mathrm{T}_{\mathrm{ap}}\right)$ in felsic volcanic rocks of the Iricoumé Group in the Pitinga Mining District have values from $799^{\circ} \mathrm{C}$ to $980^{\circ} \mathrm{C}$. Temperatures tend to decrease from trachyte to rhyolite, and apatite saturation temperatures tend to be higher even in rhyolites. Zircon saturation temperatures in rhyolites decrease from $\sim 880^{\circ} \mathrm{C}$ to $\sim 800^{\circ} \mathrm{C}$ toward the most differentiated rocks. Similarly, apatite saturation temperatures in trachytes decrease from $\sim 980^{\circ} \mathrm{C}$ to $920^{\circ} \mathrm{C}$ with the differentiation. Petrographic features indicate that zircon and apatite crystallized as early minerals in Iricoumé rhyolites and trachytes, respectively. Zircon and apatite saturation temperatures may approximate to the rhyolite and trachyte minimum liquidus temperatures. Therefore, it is assumed that liquidus temperatures for Iricoumé rhyolite melts are within the range $800-880^{\circ} \mathrm{C}$, while trachyte melts are between $910^{\circ} \mathrm{C}$ and $980^{\circ} \mathrm{C}$.

The calculated temperatures for rhyolite are in agreement with those presented by Ferron et al. (2010) for acidic rocks of the Iricoumé Group in the Pitinga area, A-type Jamon Granite and associated rocks in $\mathrm{Ca}$ rajás Metallogenic Province (between $818^{\circ} \mathrm{C}$ and $851^{\circ} \mathrm{C}$ - Dall'Agnol et al. 1999b), A-type rocks of the Lachlan Fold Belt, Australia (between $779^{\circ} \mathrm{C}$ and $873^{\circ} \mathrm{C}-$ King et al. 1997), and A-type granites and rhyolites from Grampians region, Western Lachlan Fold Belt $\left(771^{\circ} \mathrm{C}\right.$ $887^{\circ} \mathrm{C}$ - Hergt et al. 2007), all using the zircon saturation method. Furthermore, these estimations are also in agreement with experimentally determined temperatures for A-type melt $\left(>830^{\circ} \mathrm{C}-\right.$ Clemens et al. $1986 ; 770^{\circ} \mathrm{C}$ $850^{\circ} \mathrm{C}$-Dall'Agnol et al. 1999b). A temperature as high as $950^{\circ} \mathrm{C}$ was achieved experimentally by Patiño Douce (1997) for generation of A-type melts.

\section{VISCOSITY EsTIMATION}

The Giordano et al. (2008) method is calibrated to measure viscosities of silicate melt with composition varying from basanite to rhyolite at atmospheric pres- sures and temperatures from $535^{\circ} \mathrm{C}$ to $1705^{\circ} \mathrm{C}$. The viscosity estimation for rhyolite and trachyte melts through Giordano et al. (2008) model takes into account the previously calculated liquidus temperatures. Dry and hydrous conditions $(0.0-6.0 \mathrm{wt} \%)$ have been tested within the range determined by experimental works on A-type magmas (Clemens et al. 1986, Dall'Agnol et al. 1999b, Holtz et al. 2001, Klimm et al. 2003).

The calculated viscosity for Iricoumé rhyolites and trachytes on dry conditions vary from $10^{6.28} \mathrm{~Pa}$ s for the less differentiated trachyte (sample A66a) at $970^{\circ} \mathrm{C}$ to $10^{9.24} \mathrm{~Pa} \mathrm{~s}$ for the most acid rhyolite (sample A62a) at $877^{\circ} \mathrm{C}$. Water addition up to $6.0 \mathrm{wt} \%$ decreases the viscosity around five orders of magnitude for rhyolites and around four orders of magnitude for trachytes. The input of water is more effective on dry melts, pointing toward an exponential decay of viscosity as water increases. Water addition is also more effective on acid compositions, reducing from dry to 1.0 wt. $\%$ of $\mathrm{H}_{2} \mathrm{O}$ around one order of magnitude more in the sample A62a than in the A66a (Fig. 4).

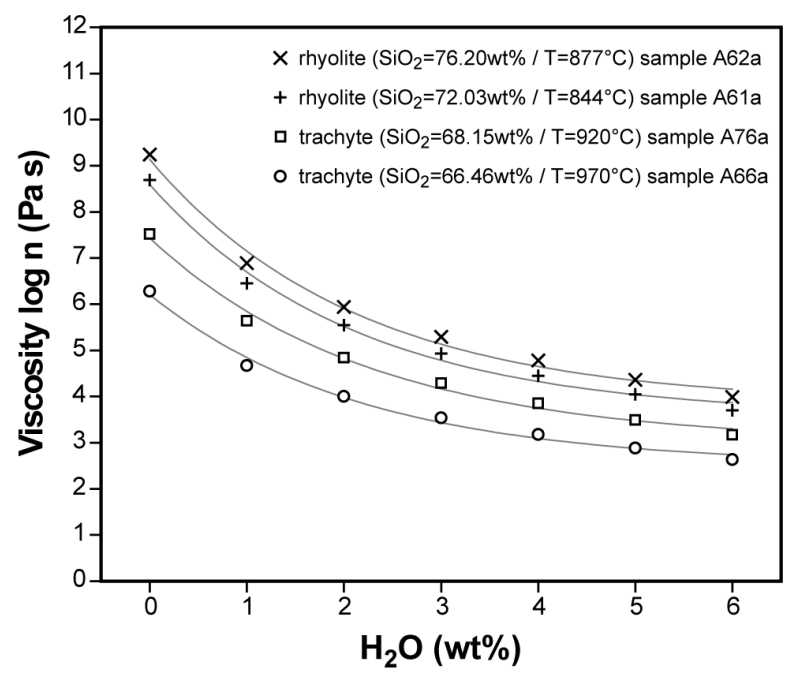

Fig. 4 - Viscosity estimation for Iricoumé samples as a function of water content. Solid lines represent best fit curves.

The slightly peraluminous rhyolite has yielded similar viscosity values to those obtained by Giordano et al. (2008) for rhyolitic melts with similar composition, within the same temperature range and under dry conditions. At 3.0 wt. \% of water, the Iricoumé rhyolite (sample A62a) has yielded viscosity values around one order of magnitude lower than those of Giordano et al. 
(2008). The viscosity values shown by one metaluminous trachyte (sample A76a) is 0.5 order of magnitude lower than those obtained by Giordano et al. (2006) for a trachytic tephra of the Campanian Ignimbrite, at the same temperature. Goto et al. (2005) presented viscosity data for dry rhyolite melts, with similar composition and temperature, around 0.5 order of magnitude higher than those calculated for the Iricoumé rhyolite (sample A62a).

Viscosity values of the Paleoproterozoic volcanic rocks of the Iricoumé Group were calculated from the whole rock analysis and assuming a similarity between the current whole rock and the original melt composition. The high crystal content in Iricoumé volcanics (up to $40 \%$ ) would imply in a magma (melt+crystals) with higher viscosities. For this calculation, the evaluation of the composition of the melt among crystals would be essential. Moreover, the non-Newtonian strain-rate dependence of viscosity in highly crystalline volcanic rocks (Webb and Dingwell 1990, Lavallée et al. 2007 and references therein) should be considered. Therefore, the estimations in this work must be considered with caution, and interpreted as an approximation of the viscosity of a melt.

\section{VOLCANIC ENVIRONMENT}

The image of Figure 5 shows the topography of the Pitinga Mining District expressed in the geological map (Fig. 1) and more fifty kilometres to the east, representing the main area of the Iricoumé occurrence. According to the topography, the area could be divided into two main domains: western and central-eastern. The western domain is flat to slightly rugged, has elevations in the range 60-100 $\mathrm{m}$ above the sea level (a.s.l.), and consists mostly of basement metamorphic rocks (Guianense Complex). The drainage system frames highly eroded terrains and depicts a fine texture, subparallel dendritic pattern, indicating stream directions coming from the boundary with the central-eastern domain toward the west and southwest. The central-eastern domain shows a more complex topographic configuration that reflects its geological heterogeneity. It is mainly rugged, with elevation levels from $80 \mathrm{~m}$ to $320 \mathrm{~m}$ a.s.l. Several drainage patterns broadly indicate a stream direction from west and north, towards the central area, and then southwards.
Areas occupied by Iricoumé volcanics are comparatively lower (mostly 100-200 m a.s.1.) and depict an extremely rugged relief with a drainage system of fine to medium dendritic pattern. In the northern portion, two semicircular features of high lands usually over $200 \mathrm{~m}$ and up to $320 \mathrm{~m}$ a.s.l. stand out. A medium to coarse dendritic drainage pattern forms another rugged relief bordering annular drainages. Mostly effusive rhyolites crops out in this area. Annular drainage patterns are widespread throughout the volcanic terrain. However, their relation with the volcanic processes could not always be directly accessed. Granitic batholiths consist of comparatively high-lands (over $200 \mathrm{~m}$ a.s.1.) with coarse dendritic, partially radial, drainage patterns. They may be locally limited by annular drainages (eastern portion of Simão Granite).

The southern portion, composed by the conglomerate-sandstone assemblage of the Urupi Formation, is characterized by flat high-lands at around $250 \mathrm{~m}$ a.s.l. There, straight drainage lines and borders step down around $150 \mathrm{~m}$ a.s.l. with incise narrow valleys. The sedimentary sequence rests over Iricoumé volcanics and dips significantly when close to the ring dike of basic rocks of the Quarenta Ilhas Formation. The elliptical topographic feature formed by the ring dikes consists of a regional structure of around $20 \times 60 \mathrm{~km}$, originally named as the Pitinga Brachysyncline (Mandetta et al. 1974, Veiga Jr. et al. 1979).

The so-called Pitinga Brachysyncline consists of an elliptical depression with annular drainage pattern at the dike margins, surrounded by higher lands where sedimentary strata dip toward the inner portion of the structure, and lower lands (100-120 m a.s.l.). The inner rugged relief is composed by sedimentary and volcanic rocks. The origin of the Pitinga Brachysyncline was originally interpreted as a tectonic structure formed by regional folding of sedimentary and volcanic beds (Mandetta et al. 1974, Veiga Jr. et al. 1979). In turn, Montalvão (1975), Araujo et al. (1976) and Dall'Agnol et al. (1999a) suggested that the Pitinga Brachysyncline formation would be related to caldera collapse processes, though a straight relation between volcanic rocks and the Pitinga Bachysyncline cannot be directly accessed through surface features. However, Ferron et al. (2007) studied in detail the co-magmatic volcanics and granitoids (from the Iricoumé Group and Mapuera 


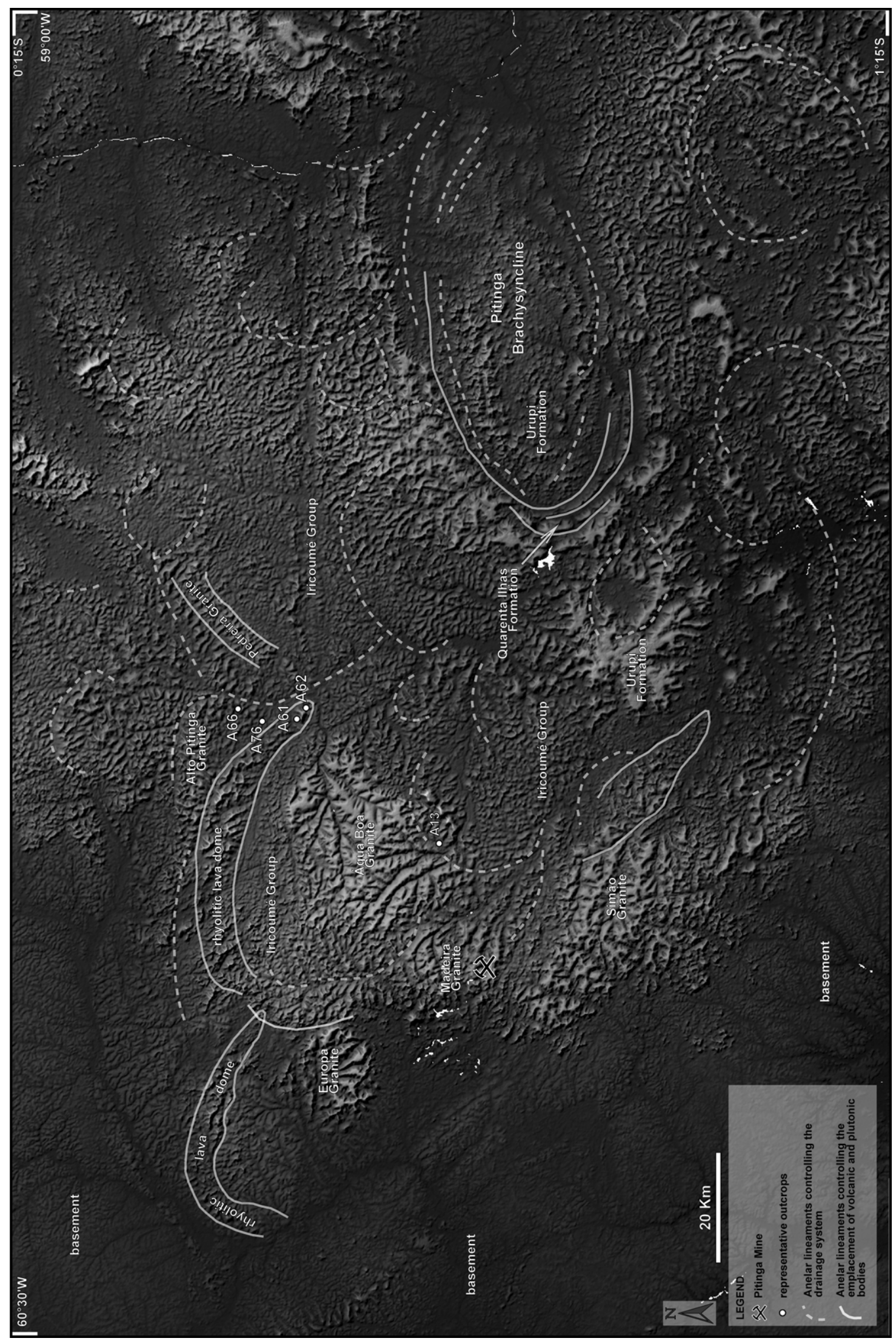

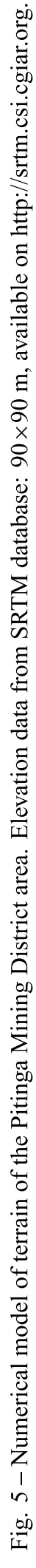


Suite, respectively) arrangement, and conclude that it widely outlines the Pitinga Bachysyncline. A caldera complex system related to the Iricoumé volcanics and Mapuera granitoids in the Pitinga Mining District was then proposed.

Despite the lack of evidences on emplacement processes of the volcanic and subvolcanic units, mainly due to their limited exposure, some discussion concerning the origin of the Iricoumé-Mapuera volcano-plutonic association can still be made. The present exposure of Paleoproterozoic volcanics in the Pitinga Mining District area indicates that the Iricoumé Group consists of a predominantly felsic volcanism (trachyte to rhyolite) mostly composed by effusive and hypabyssal rocks associated to expressive ignimbritic deposits. The ignimbrites characteristics - such as abundant juvenile and cognate fragments, enriched in denser components - indicate deposition under high temperatures. The presence of co-ignimbritic deposits suggests phreatomagmatic eruptions and/or lava dome collapse for the formation of the pyroclastic deposits. Large explosive eruptions are usually related to large silicic calderas (Newhall and Dzurisin 1988, in Gudmundsson 2008).

Two recognizable semicircular structures occur at the northern portion of the area, extending around $5 x$ $35 \mathrm{~km}$ and $5 \times 25 \mathrm{~km}$ (Fig. 5) and mostly consisting of rhyolite with subvertical flow foliation (Fig. 2c-e). The current geomorphology of these structures seems to have kept part of the lava dome original morphology. Their distribution suggests an overlapping of two structures. The emplacement of successive lava domes in the area could be associated to ring faults. Ring faults seem to have also controlled, at least partially, the emplacement of two subvolcanic granitic bodies (Simão and Pedreira Granites - Fig. 5) that have been identified as coeval with the Iricoumé volcanism (Costi et al. 2000, Ferron et al. 2007, 2010). Ring faults are usually generated from silicic caldera collapse processes or subsidence stages, and indicate shallow magma chamber (Lipman 1997, Cole et al. 2005, Acocella 2007, Gudmundsson 2008). Silicic lava domes and subvolcanic granitic bodies emplaced throughout regional ring faults frequently occur at caldera resurgence stages. Moreover, solidified plutons and batholiths emplaced within a few kilometres depth from regional volcanic surface are commonly exposed in deeply eroded ash-flow calderas.
These granitic bodies could then be interpreted as subcaldera magma chambers, which were brought to the volcanic crustal level due to tectonic uplift and erosion (Lipman 1997, Cole et al. 2005). Rhyolite caldera complexes generated by overlapping of calderas events have been recognized in the well-documented Taupo Volcanic Zone, New Zealand (Wilson et al. 1995, Cole et al. 2005, Spinks et al. 2005). Lipman (1997) and Cole et al. (2005) pointed out that the overlapping of subsidence events would result in a caldera system of complex structure and geometry rather than in a single caldera.

Paleoproterozoic sedimentary covers (Urupi Formation) and marginal faults, which were replenished by basic-intermediate intrusions (Quarenta Ilhas Formation), are the main handicap to access the genesis of the so-called Pitinga Brachysyncline and its relation with the Iricoumé volcanism. Anyhow, the area served as a preferential depositional locus for the Urupi sedimentation, and the marginal faults were deep enough to serve as preferential conduits for the basic-intermediate intrusion, 100 Ma younger than the Iricoumé volcanism. If interpreted as related to Iricoumé volcanism, the elliptical shape and large dimension of the Pitinga Brachysyncline would suggest the presence of a shallow silicic magma chamber developed within an extensional tectonic regime.

\section{CONCLUSIONS}

Geological information of the Paleoproterozoic Iricoumé volcanism, in the Pitinga Mining District reveals heterogeneous and complex configuration of the volcanic products. Detailed investigation on key outcrops supports the interpretation of the volcanic processes presented here. This is in accordance with other examples of ancient volcanic successions in the southernmost Brazil, such as the alkaline magmatism of Taquarembó Plateau (Wildner et al. 1999) and Ramada Plateau (Matos et al. 2002, Sommer et al. 2003, 2005).

Effusive units (lava and hypabyssal) have particular features, especially concerning morphology and relative abundances of phenocrysts and groundmass characteristics, which differentiate them from ignimbrites in which diagnostic features, such as fiamme and welding foliation, may not be observed. Perlitic cracks in glassy matrix and crystal and lithic fragments have been exclusively observed in the ignimbrites. Massive and partic- 
ularly stratified co-ignimbritic tuffs characteristics suggest an origin related to primary pyroclastic deposits. However, a relation with ressedimented volcaniclastic deposits is not discarded. The investigation of phenocrysts abundances and characteristics yields important information for the distinction among lava flow and dome, hypabyssal and ignimbrite units. Temperature and viscosity determination is close to experimentally measured values, suggesting that the bulk composition of Iricoumé volcanics comes up with expectations for the original melt composition.

The distribution of rhyolite dome along ring faults, the common presence of welded crystal-rich ignimbrites and co-ignimbritic tuffs, allied with subvolcanic units, such as hypabyssal rocks and shallow granitic intrusions, suggest a caldera complex system for the studied area. Structures originated during the caldera complex development seem to have controlled not only the emplacement of coeval volcanic and subvolcanic units, but also the emplacement of younger basic to intermediate intrusions. The current drainage system seems to have been strongly influenced by the imprints of the caldera setting.

\section{ACKNOWLEDGMENTS}

This paper is part of the first author thesis, which is included in the CT-Mineral project (505625/2004-0). The thesis was supported by Conselho Nacional de Desenvolvimento Científico e Tecnológico (CNPq) grant (140716/2005-0) and Coordenação de Aperfeiçoamento de Pessoal de Nível Superior (CAPES) probation grant at LMU (1432/07-9). The financial support was provided by CNPq CT-Mineral project (505625/2004-0). The authors thank Universidade Federal do Rio Grande do Sul (UFRGS) and Ludwig-Maximilians-Universität München (LMU) and their staffs, and Mineração Taboca S.A. - Paranapanema Group for the field work support and historic data availability. Authors also thank the anonymous reviewers for their comments and suggestions.

\section{RESUMO}

O Grupo Iricoumé corresponde ao mais expressivo vulcanismo Paleoproterozóico do Escudo das Guianas, craton Amazônico. As rochas vulcânicas são coexistentes com os granitóides Mapuera, e pertencem ao magmatismo Uatumã. Possuem idades U-Pb em torno 1888 Ma, e assinaturas geoquími- cas de magmas tipo-A. As vulcânicas do Iricoumé consistem de traquitos a riolitos porfiríticos, associados a ignimbritos ricos em cristal e tufos co-ignimbríticos de queda e surge. A quantidade e a morfologia dos fenocristais podem ser utilizadas para distinguir lava (fluxo e domo) de unidades hipabissais. A morfologia dos cristais em ignimbritos permite a distinção entre unidades efusivas e ignimbritos, quando os piroclastos estão obliterados. Tufos co-ignimbríticos são maciços e alguns exibem estratificações que sugerem deposição por correntes de tração. Temperaturas de cristalização de zircão e apatita variam de $799^{\circ} \mathrm{C}$ a $980^{\circ} \mathrm{C}$, são compatíveis com temperaturas de líquidos tipo-A e podem ser interpretadas como temperatura liquidus mínima. Estimativas de viscosidade para composições riolíticas e traquíticas fornecem valores próximos a de líquidos determinadas experimentalmente e ilustram curvas típicas de decaimento exponencial, com a adição de água. O posicionamento das vulcânicas Iricoumé e de parte dos granitóides Mapuera foi controlado por falhas anelares em ambiente intracratônico. Uma gênese relacionada a ambiente de complexo de caldeiras pode ser assumida para a associação vulcano-plutônica Iricoumé-Mapuera no Distrito Mineiro de Pitinga.

Palavras-chave: Craton Amazônico, complexo de caldeira, ignimbrito, vulcanismo Iricoumé, depósitos de surge, magmatismo Uatumã.

\section{REFERENCES}

ACOCELla V. 2007. Understanding caldera structure and development: an overview of analogue models compared to natural calderas. Earth Scien Rev 85: 125-160.

Albuquerque OR. 1922. Reconhecimentos geológicos no valle do Amazonas: campanhas de 1918 a 1919. Rio de Janeiro, B Serv Geol Mineral Bras 3: 1-84.

ALLEN JRL. 1982. Sedimentary structures: their character and physical basis. Amsterdam. Elsvier 1: 593.

ALLEN SR AND CAS RAF. 1998. Rhyolite fallout and pyroclastic density current deposits from phreatoplinian eruption in the eastern Aegean Sea, Greece. Journ of Volcan and Geoth Res 86: 219-251.

Allen SR AND McPhiE J. 2003. The Eucarro Rhyolite, Gawler Range Volcanics, South Australia: a $>675 \mathrm{~km}^{3}$ compositionally zoned lava of Mesoproterozoic age. Geol Soc of Am Bull 114: 1592-1609.

Araujo JFV, Montalvão RMG, Lima MiC, FernanDES PECA, CUNHA FMB, FERnANDES CAC AND BASEI MAS. 1976. Geologia da Folha SA.21 - Santa- 
rém. Brasil, Departamento Nacional de Produção Mineral. Projeto RADAMBRASIL. Folha SA.21 - Santarém. Rio de Janeiro. Levantamento de Recursos Naturais 10: 17-130.

BASEI MAS. 1977. Idade do Vulcanismo ácido a intermediário na Região Amazônica. São Paulo, 133 p. Dissertação de Mestrado em Geociências. Instituto de Geociências, Universidade de São Paulo. (Unpublished).

CAS RAF AND WRIGHT JV. 1987. Volcanic succession, modern and ancient: a geological approach to processes, products and successions. London, Allen \& Unwin, $528 \mathrm{p}$.

Clemens JD, Holloway JR ANd White AJR. 1986. Origin of an A-type granite: experimental constraints. Am Min 71: 317-324.

Cole J, Milner DM And Spinks KD. 2005. Calderas and calderas structures: A review. Earth Scien Rev 69: 1-26.

Costi HT, DAll'Agnol R And Moura CAV. 2000. Geology and $\mathrm{Pb}-\mathrm{Pb}$ Geochronology of Paleoproterozoic Volcanic and Granitic Rocks of Pitinga Province, Amazonian Craton, Northern Brazil. Int Geol Rev 42: 832-849.

Costi HT, Santiago AF And Pinheiro SDAS. 1984. Projeto Uatumã-Jatapú: análises petrográficas e mapas. Relatório Final. CPRM-SUREG-MA, Manaus, 133 p.

DADD KA. 1992. Structures within large volume rhyolite lava flows of the Devonian Comerong Volcanics, southeastern Australia, and the Pleistocene Ngongotha lava dome, New Zealand. Journ of Volc and Geoth Res 54: 33-25.

Dall'Agnol R, Bettencourt JS, Jorge Joño XS, Medeiros H, Costi HT AND MacAmbira MJB. 1987. Granitogenesis in the northern brasilian region: a review. Rev Bras Geoc 17(4): 382-403.

DALL'Agnol R, LAFON JM AND MACAMBIRA MJB. 1994. Proterozoic anorogenic magmatism in the Central Amazonian Province, Amazonian Craton: geochronological, petrological and geochemical aspects. Min and Petr 50(1/3): 113-138.

DAll'Agnol R, RÄMÖ OT, Magalhães MS AND MACAMBIRA MJB. 1999a. Rapakivi granites from Brazil and adjacent areas. Precam Res 95: 9-39.

Dall'Agnol R, Scaillet B And Pichavant M. 1999b. An experimental study of a Lower Proterozoic A-type granite from the eastern Amazonian Craton, Brazil. Journ of Petr 40(11): 1673-1698.

DERBY OA. 1877. Contribuições para a geologia da região do Baixo Amazonas. Rio de Janeiro, Arch Mus Nac 3: 77-104.

Faria MSG, Luzardo R, Pinheiro SS, Reis NJ, OliVEIRA MJR AND RIKER SRL. 2000. Projeto Caracaraí. Relatório Final. Programa de levantamentos geológicos básicos do Brasil. CPRM Caracaraí, Folhas NA.20-Z-B e NA.20-Z-D inteiras e parte das folhas NA.20-Z-A, NA.20Z-C, NA.21-Y-C e NA.21-Y-A. Estado de Roraima. Escala 1:500.000 - Brasília, CPRM. (CD-ROM).

Ferron JMTM, Bastos Neto AC, Lima EF, Costi HT, Moura CAV, Prado M, Pierosan R and Galarza MA. 2007. Geologia e geocronologia $\mathrm{Pb}-\mathrm{Pb}$ de rochas graníticas e vulcânicas ácidas a intermediárias Paleoproterozóicas da Província Pitinga, Craton Amazônico. Rev Bras Geoc 36(3): 499-512.

Ferron JMTM, Bastos Neto AC, Lima EF, Nardi LVS, Costi HT, Pierosan R ANd Prado M. 2010. Petrology, geochemistry and geochronology of Paleoproterozoic volcanic and granitic rocks (1.89 to $1.87 \mathrm{Ga})$ of the Pitinga Province, Amazonian Craton, Brazil. Journ of South Am Ear Sci 29(2): 483-497.

FISHER RV. 1979. Models of pyroclastic surges and pyroclastic flows. Journ of Volc and Geoth Res 6: 305-318.

Gifkins CC, Allen RL And MCPhie J. 2005. Apparent welding textures in altered pumice-rich rocks. Journ of Vol and Geoth Res 142: 29-47.

Giordano D, Mangiacapra A, Potuzak M, Russell JK, Romano C, Dingwell DB and Di Muro A. 2006. An expanded non-Arrhenian model for silicate melt viscosity: A treatment for metaluminous, peraluminous and peralkaline liquids. Chem Geol 229: 42-56.

Giordano D, Russell JK And Dingwell DB. 2008. Viscosity of magmatic liquids: A model. Earth and Plan Sci Lett 271: 123-134.

Goto A, TAniguchi H and Kitakaze A. 2005. Viscosity measurements of hydrous rhyolitic melts using the fiber elongation method. Bull of Volc 67: 590-596.

Gudmundsson A. 2008. Magma-chamber geometry, fluid transport, local stresses, and rock behaviour during collapse-caldera formation. In: GOTTSMANN J AND MARTi J (Eds), Caldera Volcanism: Analysis, Modelling and Response. Elsevier, Amsterdam, Developments in Volcanology 10: 313-349.

HANCHAR JM AND WATSON EB. 2003. Zircon saturation thermometry. In: HANCHAR JM AND HOSKIN PWO (Eds), Zircon. Rev in Min and Geoch 53: 89-112.

Hartmann LA AND Delgado IM. 2001. Cratons and orogenic belts of the Brazilian Shield and their contained gold deposits. Mineralium Deposita 36: 207-217.

Henry CD, Price JG, Rubin JN and Laubach SE. 1990. Case study of an extensive silicic lava: the Bracks Rhyolite, Trans-Pecos Texas. Journ of Volc and Geoth Res 43: 113-132. 
Hergt J, Woodhead J And Schofield A. 2007. A-type magmatism in the Western Lachlan Fold Belt? A study of granites and rhyolites from the Grampians region, Western Victoria. Lithos 97: 122-139.

Holtz F, Johannes W, TAmic N And Behrens H. 2001. Maximum and minimum water contents of granitic melts generated in the crust: a reevaluation and implications. Lithos 56: 1-14.

Horbe MA, Horbe AC, Costi HT And Teixeira JT. 1991. Geochemical charateristics of cryolite-tin-bearing granites from the Pitinga Mine, northwestern Brazil: a review. Journ of Geoch Expl 40: 227-249.

JANOUSEK V, FARROW CM AND ERBAN V. 2006. Interpretation of whole-rock geochemical data in igneous geochemistry: introducing Geochemical Data Toolkit (GCDkit). Journ of Petr 47(6): 1255-1259.

King PL, White AJR, Chappell BW and Allen CM. 1997. Characterization and Origin of Aluminous A-type Granites from the Lachlan Fold Belt, Southeastern Australia. Journ of Petr 38(3): 371-391.

Klimm K, Holtz F, Johannes W and King PL. 2003. Fractionation of metaluminous A-type granites: an experimental study of the Wangrah Suite, Lachlan Fold Belt, Australia. Precam Res 124: 327-341.

LAVAlléE Y, Hess KU, CORdonNier B AND DingWEll DB. 2007. Non-newtonian rheological law for highly crystalline dome lavas. Geology 35(9): 843-846.

LE Maitre RW. 2002. A classification of Igneous rocks: a classification and glossary of terms: recommendations of the international union of geological sciences subcommission of the systematic of igneous rocks. Publisher: Cambridge University Press, $2^{\text {nd }}$ ed., 252 p.

LENHARO SL. 1998. Evolução magmática e modelo metalogenético dos granitos mineralizados da região de Pitinga, Amazonas, Brasil. Tese de Doutorado. Escola Politécnica, Universidade de São Paulo, 290 p.

Lenharo SL, Pollard PJ AND Born H. 2003. Petrology and textural evolution of granites associated with tin and rare-metals mineralization at the Pitinga mine, Amazonas, Brazil. Lithos 66: 37-61.

LIPMANN PW. 1997. Subsidence of ash-flow calderas: relation to caldera size and magma-chamber geometry. Bull of Volc 59: 198-218.

Mandetta P, Veiga JR JP AND Oliveira JR. 1974. Reconhecimento geológico ao longo do rio Pitinga, afluente do rio Uatumã. CPRM/Manaus, $31 \mathrm{p}$.

Matos DF, Lima EF, Sommer CA, NArdi LVS, Liz JD, Figueiredo AMG And Pierosan R. 2002. Rio- litos Neoproterozóicos Pós-colisionais na Área do Santuário, sul do Brasil: litoquímica, química mineral e origem das heterogeneidades texturais. Rev Bras Geoc 32(2): 255-266.

Melo AFF, Santos AJ, Cunha MTP, Campos MJF And D’Antona RJG. 1978. Projeto Molibdênio em Roraima: relatório final. MME/DNPM Manaus, $6 \mathrm{v}$.

Montalvão RMG. 1975. Esboco geológico-tectônico do Craton Guianês. In: Congresso Brasileiro DE Geologia, 28. Resumo das Comunicações, SBG, Porto Alegre, p. 541-547.

Newhall CG ANd DzURISIN D. 1988. Historical unrest of large calderas of the World. Reston, VA, US Geol Surv Bull v. 1855.

Oliveira AI ANd LeOnardos OH (Eds). 1940. Geologia do Brasil. Rio de Janeiro, comissão brasileira dos centenaries Portugal, $472 \mathrm{p}$.

OLIVEIRA AS, FERNANDES CAC, ISSLER RS, MONTALVÃo RMG AND TEIXEIRA W. 1975. Geologia da Folha NA.21-Tumucumaque e parte da Folha NB.21. BRASIL, Departamento Nacional de Produção Mineral. Projeto RADAMBRASIL. Folha NA.21-Tumucumaque, e parte da Folha NB.21. Levantamento de Recursos Minerais, Rio de Janeiro 9: 21-118.

PATIÑo Douce AE. 1997. Generation of metaluminous Atype granites by low-pressure melting of calc-alkaline granitoids. Geology 25(8): 743-746.

Santos JOS, Hartmann LA, Gaudette He, Groves Di, McNaughton NJ and Fletcher LRA. 2000. New understanting of the Provinces of Amazon Craton based on Integration of Field Mapping and $\mathrm{U}-\mathrm{Pb}$ and SmNd geochronology. Gond Res 3(4): 453-488.

SANTOS JOS, HARTMANN LA, MCNAUGHTON NJ AND FLETCHER IR. 2002. Timming of mafic magmatism in the Tapajós Province (Brazil) and implications for the evolution of the Amazon Craton: evidence from baddeleyite and zircon U-Pb SHRIMP geochronology. Journ of South Am Earth Sci 15: 409-429.

Santos JOS, VAn Breemen OB, Groves Di, HartMANN LA, ALMEIDA ME, MCNAUghton NJ AND FLETCHER IR. 2004. Timing and evolution of multiple Paleoproterozoic magmatic arcs in the Tapajós Domain, Amazon Craton: constraints from SHRIMP and TIMS zircon, baddeleyite and titanite U-Pb geochronology. Precam Res 131: 73-109.

Schobbenhaus C, Hoppe A, Lork A And Baumann A. 1994. Idade $\mathrm{U} / \mathrm{Pb}$ do Magmatismo Uatumã no Norte do Craton Amazônico, Escudo das Guianas (Brasil): Primei- 
ros Resultados. In: CONGRESSo BRASILEIRO DE GEOLOGIA, 38. Anais, Balneário Camboriú, SBG 1: 395-397.

Sommer CA, Lima EF, NARdi LVS, Figueiredo AMG AND Pierosan R. 2005. Potassic and Low- and High-Ti mildly alkaline volcanism in the Neoproterozoic Ramada Plateau, Southernmost Brazil. Journ of South Am Earth Sci 18: 237-254.

Sommer CA, Lima EF, NARdi EF, Liz JD AND PieROSAN R. 2003. Depósitos de fluxo piroclástico primários: caracterização e estudo de um caso no Vulcanismo Ácido Neoproterozóico do Escudo Sul-Rio-Grandense. Rev Pesq 30(3): 3-25.

SPARKS RSJ AND WALKER GPL. 1973. The ground surge deposit: a third type of pyroclastic rock. Nat Phys Sci 241: $62-64$.

SPinks KD, Acocella V, Cole JM AND BAsset KN. 2005. Structural control of volcanism and caldera development in the transtensional Taupo Volcanic Zone, New Zealand. Journ of Volcan and Geoth Res 144: 7-22.

Tassinari CCG, Bettencourt JS, Geraldes MC, MaCAMBIRA MJB AND LAFON JM. 2000. The Amazonian Craton. In: CORDANi UG, MILANi EJ, ThOMAS FILHO A AND CAMPos DA (Eds), Tectonic Evolution of South America, Rio de Janeiro. SBG, p. 41-95.

TASSINARI CCG AND MACAMBIRA MJ. 1999. Geochronological Provinces of the Amazonian Craton, Episodes 22(3): 174-182.

VAlerio CS, SOUZA VS AND Macambira MJB. 2009. The 1.90-1.88 Ga magmatism in the center-southernmost Guyana Shield, Brazil: geology, geochemistry, zircon geochronology, and tectonic implications. Journ of South Am Earth Sci 28(3): 304-320.
Veiga Jr JP, Nunes ACB, Fernandes AS, Amaral JE, PESSOA MR AND CRUz SAS. 1979. Projeto Sulfetos de Uatumã. Relatório Final, Manaus, DNPM/CPRM, 7 v.

WATSON EB. 1979. Zircon saturation in felsic liquids: experimental data and application to trace element geochemistry. Contrib to Min and Petr 70: 407-419.

WATSON EB AND HARRISON TM. 1983. Zircon saturation revisited: temperature and composition effects in a variety of crustal magma types. Earth and Plan Sci Lett 64: 295-304.

WebB SL and Dingwell DB. 1990. The onset on nonNewtonian rheology of silicate melts - a fiber elongation study. Phys Chem Miner 17: 125-132.

Wildner W, NARdi LVS ANd Lima EF. 1999. Post-collisional alkaline magmatism on the Taquarembó Plateau: a well preserved Neoproterozoic-Cambrian Plutono-Volcanic Association in southern Brazil. Int Geol Rev 41: 1082-1098.

Wilson CJN, Noughton BF, MCWilliams MO, LANPHERE MA, WEAVER SD AND BRIGGS RM. 1995. Volcanic and structural evolution of Taupo Volcanic Zone, New Zealand: a review. Journ of Volcan and Geoth Res 68: 1-28. 